\title{
Pengaruh Video Pembelajaran Berbasis Zenius.Net Dalam Meningkatkan Motivasi Dan Pemahaman Konsep Siswa
}

\author{
${ }^{1}$ Baiq Rina Amalia Safitri, ${ }^{2}$ Lovy Herayanti \\ ${ }^{1}$ Prodi Pendidikan Teknologi Informasi, FSTT, UNDIKMA, J1. Pemuda No. 59A, Mataram, \\ Indonesia 83125 \\ ${ }^{2}$ Prodi Pendidikan Fisika, FSTT, UNDIKMA, Jl. Pemuda No. 59A, Mataram, Indonesia 83125 \\ *bqrinaamaliasafitri@ikipmataram.ac.id
}

\begin{abstract}
Abstrak: Tujuan yang ingin dicapai pada penelitian ini adalah untuk mengetahui Pengaruh Video Pembelajaran Berbasis Zenius.Net dalam Meningkatkan Motivasi dan Pemahaman Konsep Siswa. Penelitian yang digunakan adalah penelitian deskriptif kuantitatif yang dilaksanakan dengan metode penelitian Pra-eksperimental menggunakan rancangan penelitian one group pretes posttest. Sampel penelitian adalah siswa MA Anshor Beber sebanyak 17 siswa dengan teknik pengambilan sampel non probability sampling. Data dianalisis dengan metode $\mathrm{N}$-gain ternormalisasi dan paired samples t-test. Hasil penelitian menunjukkan bahwa rata-rata $\mathrm{N}$-gain pemahaman konsep siswa setelah penerapan video pembelajaran berbasis zenius.net sebesar 0,6 dengan kategori sedang. Ratarata pemahaman konsep siswa setelah perlakuan (72.2) lebih besar secara signifikan daripada sebelum perlakuan (33.8) yang dibuktikan oleh $t_{\text {hitung }}==19,6$ yang lebih besar daripada $t_{\text {kritis }}=1,8$ pada $\mathrm{dk}=15 \mathrm{dan} \mathrm{p}=0,000$. Hasil pemahaman konsep sejalan dengan hasil motivasi belajar siswa sama dengan $60 \%$ rata-rata skor ideal, maka dapat disimpulkan video pembelajaran berbasis zenius.net dapat memotivasi dan meningkatkan pemahaman konsep siswa.
\end{abstract}

\section{Kata Kunci: Video Pembelajaran, Zenius.Net, Motivasi dan Pemahaman Konsep Siswa}

Abstract: The aim of this research is to find out the Effect of Zenius.Net-Based Learning Videos in Improving Student Concept Motivation and Understanding. The research used was a quantitative descriptive study carried out with a pre-experimental research method using a one group pretest posttest research design. The sample was 17 students from Anshor Beber MA with purposive sampling technique. Data were analyzed by normalized N-gain method and paired samples t-test. The results showed that the average $\mathrm{N}$-gain understanding of students' concepts after the application of zenius.net-based learning videos was 0.6 in the medium category. The average understanding of students' concepts after treatment (72.2) is significantly greater than before treatment (33.8) as evidenced by $\mathrm{t}$ _count $==19.6$ which is greater than $\mathrm{t} \_$critical $=1.8$ at $\mathrm{dk}=15$ and $\mathrm{p}=0,000$. The results of understanding the concept are in line with the results of student motivation equal to $60 \%$ of the average ideal score, it can be concluded that zenius.net-based learning videos can motivate and improve student understanding of concepts.

\section{PENDAHULUAN}

Menurut UU SISDIKNAS Nomor 20 tahun 2003, Pendidikan adalah usaha dasar dan terencana untuk mewujudkan suasana belajar dan proses pembelajaran agar peserta didik secara aktif mengembangkan potensi dirinya untuk memiliki kekuatan spiritual keagamaan, pengendalian diri, kepribadian, kecerdasan, akhlak mulia, serta keterampilan, yang diperlukan dirinya, masyarakat, dan negara.

Belajar menurut (Slameto, 2010) merupakan suatu proses usaha yang dilakukan seseorang untuk memperoleh suatu perubahan tingkah laku yang baru secara keseluruhan, sebagai hasil pengalaman sendiri dalam interaksi dengan lingkungannya. Sedangkan, belajar dan pembelajaran menurut Hanafy (2014) merupakan dua konsep yang saling terkait satu sama lain, bagaikan dua sisi mata uang yang sulit untuk dipisahkan. Aktivitas belajar peserta didik hanya dimungkinkan berlangsung dalam suatu proses pembelajaran yang dapat memberi kesempatan bagi mereka untuk belajar dengan baik. Sebaliknya, proses pembelajaran dapat 
berlangsung dengan baik bila mendapat respons dari peserta didik. Keterkaitan antara belajar dan pembelajaran tampak pada konsep belajar dan pembelajaran.

Fahmi, dkk (2017) menyatakan kemampuan siswa dalam memecahkan masalah merupakan dampak dari rendahnya motivasi siswa. Maulida (2017) berpendapat bahwa apabila siswa benar-benar tertarik dengan pelajaran maka mereka akan belajar secara efektif. Siswa yang paham dengan materi yang diajarkan akan lebih bersemangat untuk belajar, karena siswa tidak memiliki kesulitan dalam mengerjakan tugas atau pun soal yang diberikan. Namun berbeda dengan siswa yang tidak memiliki pemahaman konsep lebih awal, mereka akan merasa malas karena tidak mengerti dengan maksud materi yang diajarkan, sehingga minat siswa dalam belajar menjadi berkurang. Menurut Mutoharo dkk, (2015) menyatakan pemahaman konsep siswa semakin baik apabila motivasi belajar siswa baik.

\section{Menurut Wina Sanjaya}

mengatakan bahwa motivasi dalam proses pembelajaran merupakan salah satu aspek dinamis yang sangat penting. Sering terjadi siswa yang kurang berprestasi bukan disebabkan oleh kemampuannya yang kurang, akan tetapi dikarenakan tidak adanya motivasi untuk belajar sehingga ia tidak berusaha untuk mengarahkan segala kemampuannya. Dimana, Mc Donald dalam Kompri (2016) menyatakan bahwa motivasi adalah suatu perubahan energi di dalam pribadi seseorang yang ditandai dengan timbulnya afektif (perasaan) dan reaksi untuk mencapai tujuan.

Motivasi merupakan salah satu faktor yang mendorong siswa untuk mau belajar. Motivasi belajar dapat diklasifikasikan menjadi dua yaitu motivasi instrinsik (keadaan keadaan yang berasal dari dalam diri siswa sendiri yang dapat mendorongnya melakukan tindakan belajar) dan motivasi ekstrinsik (keadaan yang datang dari luar individu siswa yang mendorongnya untuk melakukan kegiatan belajar). Ada tidaknya motivasi belajar sangat mempengaruhi keberhasilan belajar siswa. Keberhasilan belajar akan tercapai apabila pada diri adanya kemauan dan dorongan untuk belajar (Emda, 2017).
Berdasarkan hasil observasi bulan Maret 2020 secara langsung dan wawancara dengan guru mata pelajaran di MA Anshor ditemukan beberapa fenomena, antara lain: (1) pada saat proses pembelajaran berlangsung, guru masih mendominasi kelas, (2) siswa cenderung pasif, hanya mencatat apa yang disampaikan guru tanpa ada respon balik terhadap apa yang dicatat atau disampaikan, (3) guru dalam pembelajaran belum pernah menggunakan media pembelajaran dalam bentuk audio visual atau video dalam menjelaskan materi pelajaran.

Metode monoton seperti metode ceramah masih ditemukan di dalam proses pembelajaran, dimana guru hanya bercerita tanpa melibatkan siswa dalam suatu masalah untuk menemukan sendiri konsep pemecahan dari masalah. Hal ini pun berdampak tidak terjalin interaksi yang baik antara guru dan siswa. Tidak terjalinnya interaksi yang baik antara guru dan siswa mengakibatkan suasana belajar menjadi tidak menyenangkan. Siswa cepat merasa bosan dan terkadang memilih untuk tidak memperhatikan pelajaran. Hal tersebut mengakibatkan tidak membangkitnya motivasi siswa.

Pada umumnya pembelajaran memiliki kendala karena masih menggunakan pembelajaran konvensional dan tidak menggunakan media pembelajaran. Fasilitas multimedia dapat membuat belajar lebih menarik, visual dan interaktif. Hamalik dalam (Arsyad, 2011) menyatakan bahwa pemakaian media pembelajaran dalam proses pembelajaran dapat membangkitkan motivasi dan rangsangan kegiatan belajar, dan bahkan membawa pengaruh-pengaruh psikologi terhadap siswa. Hal ini sejalan dengan (Candralaela, dkk., 2018) Media memberikan peranan penting dalam proses pembelajaran, apabila guru tidak menggunakan media, dapat menjadikan peserta didik kurang termotivasi untuk belajar. Salah satu media pembelajaran yang dapat digunakan untuk memotivasi siswa dan sekaligus dapat meningkatkan hasil belajar siswa adalah video pembelajaran.

Dari data penelitian Gusmania dan Wulandari (2018) diperoleh $t_{\text {hitung }} \geq t_{\text {tabel }}$ $(13,62>1,98)$. Hasil penelitian menunjukan bahwa terdapat perbedaan efektivitas dalam penggunaan media pembelajaran berbasis video 
dengan pembelajaran konvensional terhadap pemahaman konsep matematis siswa. Hal ini sejalan dengan Nurdin (2019), hasil analisis data menunjukkan bahwa peningkatan kemampuan pemahaman konsep matematis siswa yang menggunakan video pembelajaran berbasis Geogebra lebih baik dibandingkan siswa yang belajar dengan pembelajaran konvensional.

Salah satu bimbingan belajar baik online atau offline yang menyediakan layanan akses pendidikan dalam format video berbahasa Indonesia adala zenius. Ada lebih dari 80.000 video pendidikan dan ratusan ribu latihan soal untuk berbagai jenjang. Mulai dari SD, SMP, SMA hingga soal-soal untuk ujian masuk perguruan tinggi (Oktaviani, Kamis, 19 Desember 2019).

Hutapea (2019) menyatakan zenius menghadirkan materi belajar berkualitas, lengkap, praktis, dan terjangkau. Lengkap maksudnya tersedia materi pelajaran dari kelas 1 SD sampai 12 SMA sesuai kurikulum KTSP, Kurikulum 2013, dan Kurikulum 2013 Revisi. Selain itu, ada materi dan soal ujian sekolah, ujian nasional, dan seleksi masuk perguruan tinggi. Tujuannya, membuat materi belajar dan pengajaran menjadi lebih dekat dan mudah diakses pelajar.

Untuk mengatasi permasalahan di atas, maka peneliti mengambil judul "Pengaruh Video Pembelajaran Berbasis Zenius.Net dalam Meningkatkan Motivasi dan Pemahaman Konsep Siswa".

\section{METODE}

Penelitian yang digunakan adalah penelitian deskriptif kuantitatif yang dilaksanakan dengan metode penelitian Praeksperimental menggunakan rancangan penelitian one group pretes posttest. Desain penelitian dilihat pada Tabel 1.

\begin{tabular}{|l|l|l|}
\hline Pretes & Perlakuan & Postes \\
\hline $\mathrm{O}_{1}$ & $\mathrm{X}$ & $\mathrm{O}_{2}$ \\
\hline
\end{tabular}

Sumber: Pahriah dan Hendrawani, 2019

Keterangan:

$\mathrm{O}_{1} \quad$ : pretes

$\mathrm{O}_{2}$ : postes

$\mathrm{X}$ : pengguna zenius.net

Objek dari penelitian ini adalah pengaruh video pembelajaran berbasis zenius.net dalam meningkatkan motivasi dan pemahaman konsep siswa. Subjek penelitian adalah siswa kelas X dan kelas XI MA Anshor Beber. Teknik pengambilan sampel menggunakan teknik non probability sampling yakni dengan sampling jenuh (sensus) yaitu metode penarikan sampel bila semua anggota populasi dijadikan sebagai sampel. Hal ini sering dilakukan apabila jumlah populasi kecil, kurang dari 30 orang (Supriyanto dan Machfudz, 2010), dalam penelitian ini sebanyak 17 siswa. Mata pelajaran yang terdapat di MA Anshor bergantung dari sumber daya manusia atau tenaga pengajar yang terdapat pada sekolah tersebut, sehingga peneliti memutuskan materi penelitian pada mata pelajaran matematika yaitu materi pangkat dan program linier.

Data penelitian dikumpulkan menggunakan instrumen tes pemahanan konsep siswa yang terdapat di zenius.net. Skor pemahaman konsep yang diperoleh diolah menjadi skor dalam bentuk presentasi dengan menggunakan rumus:

Nilai yang diperoleh $=\frac{\text { Skor yang diperoleh }}{\text { Skor maksimum }} \mathrm{x}$ $100 \%$

Siswa dinyatakan memiliki pemahaman konsep apabila mencapai persentasi 51\%-100\%. Kualitas peningkatan pemahaman konsep diperoleh melalui perhitungan $\mathrm{N}$-gain yang dikategorikan berdasarkan Tabel 2.

$$
\mathrm{N}-\text { gain }=\frac{\mathrm{S}_{\text {post }}-\mathrm{S}_{\text {pre }}}{\mathrm{S}_{\mathrm{Gmax}}-\mathrm{S}_{\text {pre }}}
$$

Tabel 2. Kriteria Perolehan Skor N-gain

\begin{tabular}{|l|l|}
\hline $\mathrm{N}$-gain & Kriteria \\
\hline $\mathrm{g}>0,7$ & Tinggi \\
\hline $0,3 \leq \mathrm{g} \leq 0,7$ & Sedang \\
\hline $\mathrm{g}<0,3$ & Rendah \\
\hline
\end{tabular}

Sumber: Riduwan \& Akdon, 2013

Signifikansi peningkatan pemahaman konsep siswa ditentukan melalui uji hipotesis satu arah menggunakan uji t sampel berpasangan (paired sampel $t$ test) yang dihitung dengan bantuan Ms. Office Excel for Windows. Adapun hipotesis yang diuji dinyatakan sebagai berikut:

$\mathrm{HO}$ : pengaruh video pembelajaran berbasis zenius.net dalam meningkatkan pemahaman konsep siswa tidak lebih besar secara signifikan daripada sebelum perlakuan. 
Ha : pengaruh video pembelajaran berbasis zenius.net dalam meningkatkan pemahaman konsep siswa lebih besar secara signifikan daripada sebelum perlakuan.

Pengujian sampel motivasi belajar siswa menggunakan uji satu pihak untuk satu pihak kiri, dengan rumus:

$$
t_{\text {hitung }}=\frac{x-\mu}{\frac{s}{\sqrt{n}}}
$$

\section{HASIL DAN PEMBAHASAN}

Jumlah siswa yang mengikuti pretes sebanyak 17 orang. Pelaksanaan postes dilakukan setelah siswa selesai dibelajarkan dengan video pembelajaran berbasis zenius.net. Soal postes memiliki isi yang sama dengan pretes dan jeda waktu antara pretes-postes yaitu tiga minggu. Soal pretes dan postes yang diberikan kepada siswa 10 soal yang berorientasi pemahaman konsep siswa. Pada Tabel 3 disajikan rekapitulasi hasil pretes dan postes pemahanan konsep siswa MA Anshor.

Tabel 3. Hasil pretes dan postes pemahanan konsep siswa

\begin{tabular}{|l|r|r|r|l|}
\hline No Absen & Pre & Post & N-gain & Kriteria \\
\hline Siswa 1 & 30 & 67 & 0.5 & Sedang \\
\hline Siswa 2 & 35 & 67 & 0.5 & Sedang \\
\hline Siswa 3 & 35 & 70 & 0.5 & Sedang \\
\hline Siswa 4 & 30 & 70 & 0.6 & Sedang \\
\hline Siswa 5 & 40 & 67 & 0.5 & Sedang \\
\hline Siswa 6 & 40 & 68 & 0.5 & Sedang \\
\hline Siswa 7 & 30 & 70 & 0.6 & Sedang \\
\hline Siswa 8 & 30 & 65 & 0.5 & Sedang \\
\hline Siswa 9 & 30 & 65 & 0.5 & Sedang \\
\hline Siswa 10 & 35 & 65 & 0.5 & Sedang \\
\hline Siswa 11 & 35 & 75 & 0.6 & Sedang \\
\hline Siswa 12 & 40 & 80 & 0.7 & Sedang \\
\hline Siswa 13 & 35 & 85 & 0.8 & Tinggi \\
\hline Siswa 14 & 30 & 75 & 0.6 & Sedang \\
\hline Siswa 15 & 40 & 77 & 0.6 & Sedang \\
\hline Siswa 16 & 30 & 77 & 0.7 & Sedang \\
\hline Siswa 17 & 30 & 85 & 0.8 & Tinggi \\
\hline Rata-rata & 33.8 & 72.2 & 0.6 & Sedang \\
\hline
\end{tabular}

Tabel 3 di atas menunjukkan adanya peningkatan pemahaman konsep siswa yang dilihat dari nilai $\mathrm{N}$-Gain setiap siswa. Secara umum dapat diketahui bahwa sebanyak 15 siswa mendapatkan nilai gain kategori sedang dan ada 2 siswa yang mendapat gain kriteria tinggi. Berdasarkan data pemahaman konsep, diketahui rata-rata pemahaman konsep siswa sebelum diterapkan video pembelajaran berbasis zenius.net sebesar 33.8 dan nilai minimum yang didapatkan sebesar 30 serta nilai maksimumnya sebesar 40. Rata-rata pemahaman konsep setelah diajarkan dengan menggunakan video pembelajaran berbasis zenius.net sebesar 72.2 dengan nilai minimum sebesar 65 serta nilai maksimum sebesar 85. Kemudian dilanjutkan dengan uji hipotesis satu arah menggunakan uji t sampel berpasangan (paired sample $t$ test) yang dihitung dengan bantuan Ms. Office Excel for Windows, data selengkapnya dapat dilihat pada Tabel 4.

Tabel 4. Data hasil analisis pretes dan postes

\begin{tabular}{|l|r|r|}
\hline & \multicolumn{1}{|c|}{ Pret } & \multicolumn{1}{c|}{ Post } \\
\hline Mean & 34.0625 & 72.5625 \\
\hline Variance & 17.3958333 & 45.9958 \\
\hline Observations & 3 & 3 \\
\hline $\begin{array}{l}\text { Pearson } \\
\text { Correlation }\end{array}$ & 0.03166980 & 16 \\
\hline Hypothesized & 2 & \\
Mean Difference & 0 & \\
\hline Df & 15 & \\
\hline & - & \\
& 19.6214168 & \\
t Stat & 7 & \\
\hline P(T<=t) one-tail & $2.08054 \mathrm{E}-12$ & \\
\hline & 1.75305032 & \\
t Critical one-tail & 5 & \\
\hline
\end{tabular}

Dari hasil analisis statistik pada Tabel 4 diperoleh t hitung 19,6 lebih besar daripada $t$ kritis 1,8 pada $\mathrm{dk}=15$ dan $\mathrm{p}=0,000$. Oleh karena itu dapat disimpulkan bahwa penerapan video pembelajaran berbasis zenius.net dapat meningkatkan pemahaman konsep siswa.

Hasil pemahaman konsep sejalan dengan hasil motivasi belajar siswa, dimana $t_{\text {hitung }}=1.9$, dengan menguji satu pihak untuk pihak kiri, maka diperoleh $t_{\text {tabel }}=-1.8$. Jika $t_{\text {hitung }}=$ $1.9>t_{\text {tabel }}=-1.8$ maka dapat disimpulkan video pembelajaran berbasis zenius.net dapat memotivasi belajar siswa sama dengan $60 \%$ ratarata skor ideal. 
Bentuk dari penyajian materi dan pembahasan soal di zenius.net berupa video, seperti gambat di bawah ini.
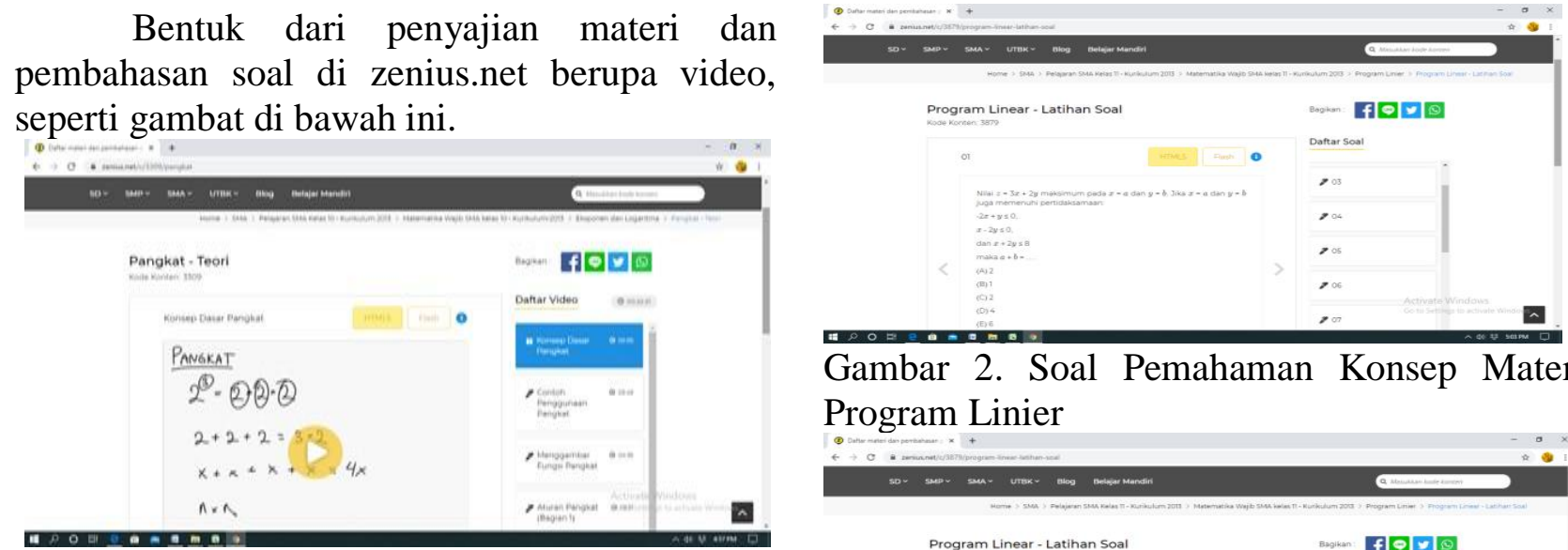

Gambar 1. Materi Pangkat

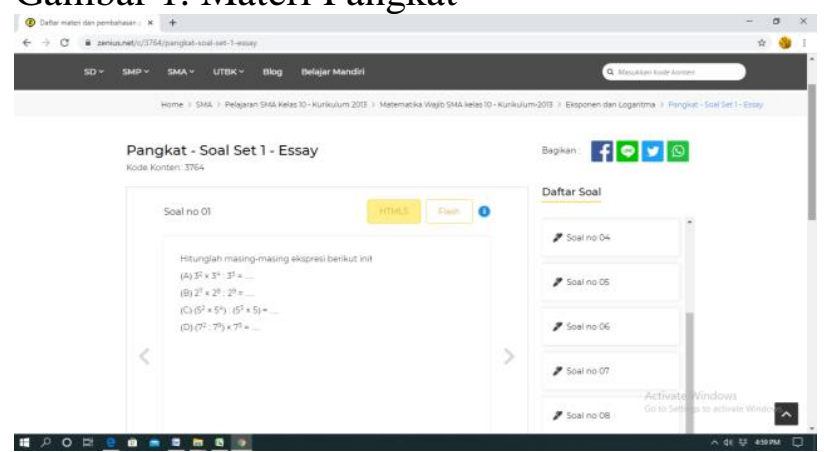

Gambar 2. Soal Pemahaman Konsep Materi

Pangkat
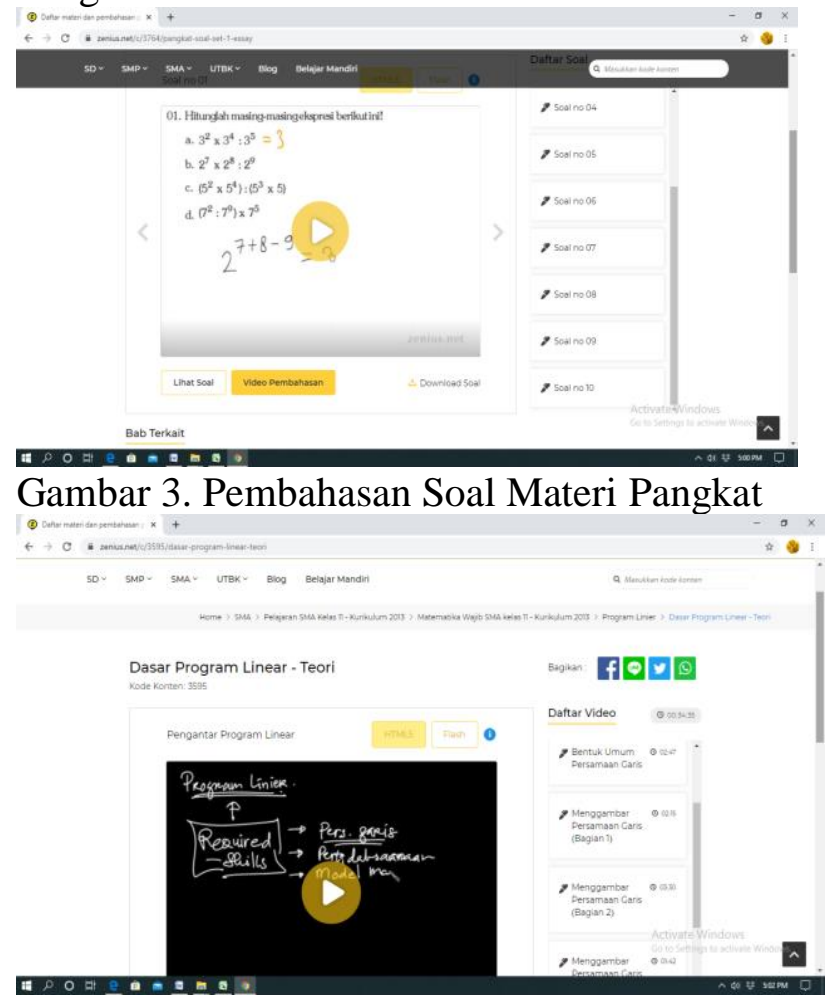

Gambar 2. Materi Program Linier

Gambar 2. Soal Pemahaman Konsep Materi Program Linier

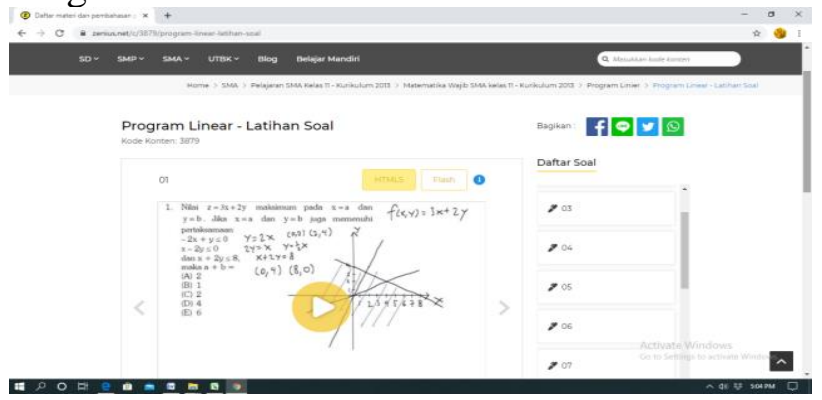

Gambar 3. Pembahasan Soal Materi Program Linier

Pemahaman konsep siswa berada pada kriteria sedang. Hal ini ditunjukkan oleh nilai $\mathrm{N}$ gain sebesar 0,6. Hasil ini menunjukkan bahwa Video Pembelajaran Berbasis Zenius.Net dapat membantu siswa memahami konsep dengan lebih baik.

\section{KESIMPULAN}

Hasil penelitian menunjukkan bahwa rata-rata $\mathrm{N}$-gain pemahaman konsep siswa setelah penerapan video pembelajaran berbasis zenius.net sebesar 0,6 dengan kategori sedang. Rata-rata pemahaman konsep siswa setelah perlakuan (72.2) lebih besar secara signifikan daripada sebelum perlakuan (33.8) yang dibuktikan oleh $t_{\text {hitung }}=19,6$ yang lebih besar dari pada $t_{\text {kritis }}=1,8$ pada $\mathrm{dk}=15$ dan $\mathrm{p}=0,000$. Hasil pemahaman konsep sejalan dengan hasil motivasi belajar siswa sama dengan $60 \%$ ratarata skor ideal, maka dapat disimpulkan video pembelajaran berbasis zenius.net dapat memotivasi dan meningkatkan pemahaman konsep siswa.

\section{SARAN}

Selain memanfaatkan Zenius.Net untuk belajar, juga dapat memanfaatkan situs-situs bimbingan belajar gratis lainnya, pembelajaran berbasis zenius ini direkomendasikan hanya pada sekolah-sekolah yang memiliki fasilitas pembelajaran online. 


\section{UCAPAN TERIMA KASIH}

Ucapan terima kasih kepada yayasan pembina IKIP Mataram atas support dananya.

\section{DAFTAR PUSTAKA}

Arsyad. (2011). Media Pengajaran. Jakarta: Raja Grafindo Persada.

Candralaela, dkk. (2018). Penerapan Video Pembelajaran Untuk Peningkatan Kompetensi Pekerjaan Sosial Pada Peserta Didik Di SMKN 15 Bandung. Jurnal Family Edu, 4(2), 82-92.

Emda, Amna. (2017). Kedudukan Motivasi Belajar Siswa dalam Pembelajaran. Lantanida Journal, 5(20, 93-196.

Fahmi, dkk. (2017). Penerapan Metode Pembelajaran Problem SolvingUntuk Meningkatkan Motivasi dan KemampuanPemecahanMasalah Matematika SiswaKelas VIII B. JMPM, 5(1), 85-89.

Gusmania, Y \& Wulandari, T. (2018). Efektivitas penggunaan media pembelajaran berbasis video Terhadap pemahaman konsep matematis siswa. Pythagoras. 7(1), 61-67.

Hanafy, Muh., Sain. (2014). Konsep Belajar dan Pembelajaran. Jurnal Lentera Pendidikan, 17(1), 66-79.

Hutapea, E. (2019). Pengalaman Belajar Belum Menyenangkan, Zenius Rilis Aplikasi "Mobile". (Retrieved Februari 11, 2020, from

KOMPAS.COM:https://edukasi.kompas. com/read/2019/07/17/21050881/pengala man-belajar-belum-menyenangkanzenius-rilis-aplikasimobile?page=all).

Kompri. (2016). Motivasi Pembelajaran Perspektif Guru dan Siswa. Bandung: PT Rosda Karya.

Maulida, dkk. (2017). Analisis Pemahaman Konsep Siswa Pada Materi Persamaan Lingkaran Ditinjau Dari Motivasi Belajar Siswa Kelas Xii Ips 4 SMA Negeri 6 Surakarta Tahun Pelajaran 2016/2017. Jurnal Pendidikan Matematika dan Matematika (JPMM), 1(4), 26-45.

Mutoharo,dkk. (2015). Hubungan Motivasi Belajar Terhadap Pemahaman Konsep

Jurnal Ilmu Sosial dan Pendidikan
IPA pada Siswa Kelas VIII SMP Negeri 21 Surabaya. e-Journal UNESA (Pendidikan Sains), 3(2), 1-9.

Nurdin,dkk. (2019). Pemanfaatan video pembelajaran berbasis Geogebra untuk meningkatkan kemampuan pemahaman konsep matematis siswa SMK. Jurnal Riset Pendidikan Matematika, 6(1), 8798.

Oktaviani, Saradita. (2019). Zenius Education. (Diakses tanggal 7 Juni 2020, https://www.tribunnewswiki.com/2019/1 2/19/zenius-education).

Pahriah dan Hendrawani. 2019. Efektivitas Modul Inkuiri dengan Strategi Konflik Kognitif Dalam Meningkatkan Keterampilan Berpikir Kritis Mahasiswa. Hydrogen: Jurnal Kependidikan Kimia, 7(2), 62-72.

Riduwan \& Akdon. (2013). Rumus dan Data dalam Analisis Statistika (Z. Arifin, Ed.). Bandung: Alfabeta.

Sanjaya, Wina. (2010). Kurikulum dan pembelajaran, Teori dan praktek Pengembangan Kurikulum KTSP. Jakarta: Kencana.

Slameto. (2010). Belajar dan Faktor-faktor yang Mempengaruhinya. Jakarta: PT. Rineka Cipta.

Supriyanto, Achmad Sani. dan Masyhuri Machfudz. (2010). Metodologi Riset: Manajemen Sumberdaya Manusia. Malang: UIN-Maliki Press.

Undang-undang Republik Indonesia Nomor 20 Tahun 2003 Tentang Sistem Pendidikan Nasional. 